\title{
The Cinema of Jans Rautenbach
}

\author{
By Martin P. Botha \\ Fall 2015 Issue of KINEMA

\section{THE ANGUISH OF A DREAMER: $A B R A H A M$ (2014) AND THE CINEMA OF JANS RAUTENBACH}

\section{Introduction: Rautenbach's cinema}

A few pioneers in the Afrikaans film industry of the sixties produced a number of films that could be labelled "involved films". The theme of these films was an examination of the cracks in apartheid ideology. They included Emil Nofal-Jans Rautenbach's films like Die Kandidaat (The Candidate, 1968) and Katrina (1968).

Several film historians regard Jans Rautenbach as the pioneer of modern, bold and South African filmmaking in the 1960s and 1970s. Together with producer Emil Nofal he made ground-breaking films during a time when South African cinema hardly reflected the socio-political realities of the country.

Born in 1936 in Boksburg, Jansen Delarosa Rautenbach grew up in a very poor household. His father worked in the mines. He started his school years at a primary school in Boksburg. Early influences in his life were literature, not cinema. After studying theology at the University of Stellenbosch for three years, Rautenbach decided that it was not his calling, and he moved to Bloemfontein. While working as a clerk in a government department he studied criminology at the University of the Orange Free State. In January 1960 he accepted a position as criminologist in the Central Jail in Pretoria. But on 12 February 1963, he gave 24-hour notice to leave and work in the film industry.

He started his film career as a production manager for Jamie Uys Films but joined Emil Nofal later in 1963 to start a new company, Emil Nofal Films. Nofal's King Hendrik (1965) is a satire about relationships between Afrikaans and English-speaking white South Africans and thus followed in the comedic tradition of Jamie Uys's Hans en die Rooinek (1961) and Lord Oom Piet (1962). The film included actors and crew members who later worked on the set of Rautenbach-directed features: actors Marié du Toit and Joe Stewardson, cinematographer Vincent Cox and editor Peter Henkel. The film was made during the time of very strict moral and political censorship in South Africa (Tomaselli 1989). The result was self-censorship by scriptwriters and directors, and two decades of film escapism. Comedies, musicals, adventure stories and tales about wildlife and nature dominated local film production during the 1960s (Botha \& Van Aswegen 1992; Botha 2012).

Nofal was one of the few English-language filmmakers of the 1960s who made Afrikaans language films. Born in 1926 in Johannesburg to ethnic Lebanese parents, Nofal started his career at the young age of 15 years at the Killarney Film Studios. He worked there for 13 years, first as assistant editor, then as cinematographer and finally as director of features such as Song of Africa (1951), a musical to present black talent including the African Inkspots.

Owing to the fact that the subsidy scheme provided no developmental money, filmmakers had to look for funding elsewhere. Joop Rijfkogel from Irene Film Laboratories became a major funder of Rautenbach's films. Nofal and Rautenbach combined their unique talents on Wild Season (1967), an acclaimed drama about the conflict between a father and his son, set against the backdrop of a fishing community along the west coast of South Africa. It was based on the song "It Was a Very Good Year", which Nofal loved. The film depicts one season in the lives of a fishing community by focusing on personal conflicts, love and an early death.

Dirk Maritz (an impressive performance by Gert Van den Bergh) has been a lonely and embittered man after the mysterious death of his older son at sea. He is a top fisherman and a symbol of perseverance of Afrikaners against the violence of nature as well as their own personal problems. Maritz does not accept his younger son, the sensitive Michael (Antony Thomas). This leads to the dramatic conflict in the film, which in many ways examines Afrikaner patriarchy. Another strong theme is the short, single season of young love 
between Jess (Janis Reinhardt) and Michael. The approach to the subject matter is lyrical, an important characteristic of all Rautenbach's films.

Wild Season featured many members of later Rautenbach films: Joe Stewardson, Marié du Toit, Vincent Cox, Peter Henkel and composer Roy Martin. Rautenbach built a professional relationship with a group of actors and crew members who shared his artistic vision and enabled him in using the film medium for personal expression as an auteur. Rautenbach developed a central theme around the identity of the Afrikaner ${ }^{(1)}$ in all his subsequent films, from Die Kandidaat to Broer Matie (1984). His films differ from the previous Afrikaans cinema in the sense that Rautenbach regarded film as an art form and thus a means for personal expression.

The next three projects Rautenbach directed became milestones in South African cinema. In his directorial debut, Rautenbach examines various aspects of the urban (white) Afrikaner through the events surrounding the election of a new director for the Adriaan Delport Foundation in the acclaimed melodrama Die Kandidaat (1968). As the backgrounds of the potential candidates have been thoroughly checked the appointment should be a mere formality.

Instead the meeting degenerates into a bitter dispute over which one of the council members satisfy the requirements of genuine Afrikanerdom. Die Kandidaat explores the Afrikaner psyche critically and exposes the hypocrisy of those designated as "super" Afrikaners. Drawing heavily on his own background in psychology, Rautenbach presents the viewer with various Afrikaner types and in the process dissects the psyche of white Afrikanerdom. Funding came from four Dutch-speaking individuals: Joop Rijfkogel, Boogertman, Ruijter and Klaver. The latter three funders were part of the building industry. Rautenbach received R150,000 for the production and wrote the screenplay before the start of production. He also conducted intense auditions for actors. He asked Gert Van den Berg to play a lead role.

Actors were cast based on their ability to portray three-dimensional characters and not on their looks. In many ways this was a major departure from former Afrikaans cinema. The Adriaan Delport Foundation in the film is a metaphor for the Akademie vir Wetenskap en Kuns (Academy for Science and Arts), an Afrikaner organisation at the time committed to the promotion of the interests of the Afrikaner. In 1965 and 1966 two groups within Afrikanerdom debated Prime Minister Hendrik Verwoerd's apartheid ideology. A more enlightened group including Schalk Pienaar, the editor of the newspaper Beeld, who had serious doubts about Verwoerd's homelands-for-blacks policy, especially concerning its practicality. Pienaar questioned Afrikaner traditions and encouraged a more open approach to race relationships in South Africa (Botha 2006). He raised questions about the multicultural realities of South Africa and the fact that these realities needed to be taken into account in the country's future political direction. Afrikaner conservatives, however, argued for an exclusive South African state for whites and especially white Afrikaners.

In Die Kandidaat, the Delport Foundation is looking for a new director to replace one who had died. Based on the recommendations by the chair of the board, Lourens Niemand (Gert Van den Bergh), and a board member, Paula Neethling (Marié du Toit), one candidate - Dr. Jan le Roux - is proposed. He is known for his work at a centre for the rehabilitation of boys who had committed offences in society.

The selection process, however, turns out to be a dissection of the candidate's background, including his love relationships. The major catalyst in the process is a writer of the sixties, Anton du Toit (Cobus Rossouw). The bone of contention is that Le Roux is engaged to an English-speaking girl from a Catholic background. The board members are representatives of the broader Afrikaner community, for example, a professor, a Dutch Reformed Church parson, a state bureaucrat, a truck driver and a woman, who rigidly protects the morals of the Afrikaner nation.

Most of the action is confined to the boardroom where the debate about Afrikaner identity is taking place. It is a claustrophobic setting, which has been brilliantly explored by means of Vincent Cox's camera set-ups and movements as well as an impressive use of mise-en-scène. While the debate unfolds in the board room, the camera focuses on the artefacts of previous Afrikaner leaders in the form of statues and paintings in the background. They seem to observe the conflict as a silent but dominant collective presence.

Jannie Kruger, chief state censor of the 1960s, had major objections against the film, especially regarding conversations about whether the so-called Cape "coloureds" (South Africans of mixed race who are Afrikaans speaking - see endnote 1) could be considered Afrikaners. 
Rautenbach refused to make cuts and started a debate about the film's censorship problems in the Afrikaans print media with the assistance of enlightened media friends such as Schalk Pienaar and Tobie Boshoff. In a way Kruger received negative publicity. Finally Rautenbach and Kruger reached a compromise regarding the dialogue, and the film was released to wide acclaim by both the Afrikaans and English press. It was regarded as a film equivalent to the literary work by a progressive group of Afrikaans writers, which included Etienne Leroux, André P. Brink, Breyten Breytenbach and Jan Rabie (Botha 2006).

In Die Kandidaat Rautenbach made the statement that the white Afrikaner is going to create a madhouse for himself with all his ideologies and dogmas. From the Afrikaner political right, Rautenbach was accused of humiliating the Afrikaner. The film introduced the major thematic concern in his oeuvre, namely who and what is the Afrikaner? Who could be regarded as a "true" Afrikaner? In the process Rautenbach also examined class and ideological differences and viewpoints within Afrikanerdom.

Another important departure from previous Afrikaans cinema has been the clinical, modern and urban setting of Die Kandidaat. It is far removed from the pastoral landscapes of earlier Afrikaans features. The setting symbolised the material wealth of Afrikaners towards the end of the 1960s due to their privileged position in Verwoerd's apartheid state. The character of Paula Neethling is especially of significance: She is cold and manipulative. Paula is part of a new elite class, a new bourgeoisie. Du Toit's performance is simply perfect.

Three other Afrikaner types depicted are also important: The writer Anton du Toit (Cobus Rossouw), the woman who protects the morals of the nation (Hermien Dommisse) and the Dutch Reformed parson (Jacques Loots). Du Toit functions as a type of mouthpiece for Rautenbach, a liberal voice and the one who pulls off the mask of Afrikaner bias. He is symbolic of a more enlightened generation of Afrikaners. Du Toit is intellectual and brutally honest. The Dutch Reformed parson has a dignified presence but lacks a strong ability to lead. Hermien Dommisse's remarkable depiction of the volksmoeder (mother of the nation) displays her stubbornness and sad ignorance of the changing realities and values in Afrikaner society. She is still clinging to an era of outdated morality. In Jannie Totsiens (1970), this character will be confined to an asylum.

After the critical acclaim for Die Kandidaat Rautenbach directed Katrina (1969), one of the most innovative films to come out of the apartheid years of the sixties. Based on a powerful play by D. Warner, Try for White, this is, for its time, a shocking expose of the horrors of apartheid and the racial classification system. The film focuses on a "coloured" woman, Katrina, who "tries for white". She renounces her mother and father to make a better life possible for herself and her son in apartheid South Africa. Her son is unaware of his roots and is dating a white girl (played by Katinka Heyns). A white Anglican priest, Alex Trewellyn, falls in love with Katrina, and their lives are shattered when the secrets are revealed. The film showcases the talents of Rautenbach's regular team of actors and crew members: Joe Stewardson as the Anglican priest, Carl Trichardt as the father of the white girl and Regardt Van den Bergh as her racist brother. Cobus Rossouw is brilliant as a "coloured" community leader who displays bitterness towards the white community. He serves as the catalyst of the story in the sense that he exposes Katrina and her son's real identity with tragic consequences. Don Leonard's portrayal of Katrina's "coloured" husband is moving.

Once again the crew included cinematographer Vincent Cox, Peter Henkel as editor and composer Roy Martin. Rautenbach received death threats from the far right wing in South Africa and had to battle the censors in South Africa to make this film. Chief censor Jannie Kruger wanted to cut several scenes (Botha 2006). Rautenbach once again involved media friends such as Schalk Pienaar to create a debate. Together with journalist Rykie Van Reenen and literary giant N.P. Van Wyk Louw, Pienaar initiated a defence of the film and freedom of expression in the newspaper Beeld. The debate created an impression that a part of the Afrikaner nation was against Kruger's censorship demands. Kruger wanted to ban the film or destroy it by means of extensive cuts. At the end of the film Katrina commits suicide. Rautenbach makes the statement that the racial classification system created a cruel reality that drives South Africans to suicide.

Katrina continues Rautenbach's theme of cultural identity. In this case the impact of the apartheid state on the identities of South Africans has been examined, together with white racism and the biases of the white Afrikaner nation. After the production of Katrina, Rautenbach and Nofal decided to terminate their professional relationship. Rautenbach established his own production company, Sewentig. 
In Jannie Totsiens (1970), his next feature, Rautenbach uses a mental institution as an allegory of South African society under apartheid. This was South Africa's first avant-garde film, which caused a sensation, especially among the intellectuals of the time (Botha 2006).

Again using Afrikaner types Rautenbach examines the Afrikaner psyche. In Katrina and Die Kandidaat Rautenbach used the conventions of melodrama to reach a larger audience. In Jannie Totsiens his approach is avant-garde. There is no classical narrative structure to speak of. The situation in the film represents a microcosm of South Africa in 1970. The apartheid state has been represented as an asylum. The inmates are Afrikaner types such as a political right-winger (Don Leonard), a judge (Jacques Loots), a painter without arms, a girl with the mind of a child (Katinka Heyns) as well as an alienated English woman and one black person. The institution is a private asylum that was created for Magda du Plessis (Hermien Dommisse). In Die Kandidaat she played the guardian of the nation's morals. Here she still practises this role by guarding over the other patients. With the assistance of her aggressive cats she ensures that nobody behaves in a manner that is morally unacceptable. Jannie (Cobus Rossouw) is a new patient. He does not even speak initially. The outspoken writer of Die Kandidaat initially has no voice in Jannie Totsiens. The character functions as a symbol of the state of critical voices in the arts during the apartheid system.

The brilliance of Jannie Totsiens can be attributed to Rautenbach's directing, the performance of the acting ensemble and the cinematography by David Dunn-Yarber and Koos Roets. The film has the feel of a psychological thriller and the experimentation with colour, mise-en-scène and sound was unrivalled in contemporary South African cinema.

The film, however, was an isolated case in South African cinema during the 1970s. Escapism dominated the output of the film industry. The images of Afrikanerdom by Rautenbach in Jannie Totsiens certainly did not meet the expectations of audiences. They rejected these films and rather flocked to those who portrayed them as chatty, heart-warming and lovable. Their conception of socio-political reality was confined to the conventions of Afrikaans melodramas about mismatched couples who had to overcome obstacles on the path to true love! Sadly, severe moral censorship prevented South Africans from viewing international landmarks such as Fellini's Satyricon (1969), Bertolucci's Last Tango in Paris (1972) and Pontecorvo's The Battle of Algiers (1966), which at that critical stage would have challenged our conceptions of sexuality, politics, race and aesthetics.

Jannie Totsiens was part of political modernism in world cinema. Although South African audiences were not ready for this stimulating psychological drama, which has challenged Afrikanerdom's conservative culture, it remains, even by today's standards, a fascinating portrait of a nation's confused psyche and it anticipated developments in South African politics during the 1980s.

Rautenbach's next film, Pappa Lap (1971), deals with class divisions within Afrikanerdom and especially with the marginalised section of white Afrikaners, the very poor, who in the context of the film live as bywoners. Class divisions within Afrikanerdom were also explored in Eendag op 'n Reëndag (1975). Both films benefited from brilliant cinematography by Koos Roets and outstanding performances by Katinka Heyns.

Rautenbach's second last feature, Broer Matie (1984), returned to the political discourse of Katrina and Die Kandidaat. Broer Matie is a gripping melodrama dealing with the unsettling political background of 1961 in South Africa. With happenings like the Sharpeville massacre still fresh in everyone's mind, the main character causes furore in a rural community when his last will and testament determines that a church minister of colour should conduct the sermon at his funeral. As in the case of Die Kandidaat, Rautenbach exposes the hypocrisy of white Afrikaners and the importance for this part of the South African community to accept and face a multicultural society in which everyone should be treated as equal. The film was made a decade before the historical elections in 1994, which led to a government of national unity in South Africa.

Rautenbach never wanted to work for the South African Broadcasting Corporation (SABC) and thus stopped making features after 1984. He became instrumental in the establishment of the Klein Karoo National Arts Festival (KKNK) in 1994, which has developed into one of the largest national arts festivals in South Africa.

He is currently living on a farm, Oulap, in the Little Karoo of South Africa. Rautenbach's work was featured in many international film festivals, including the 1989 Weekly Mail Film Festival, Kriterion's Focus on South Africa in Amsterdam, Utrecht and Den Haag in 1995 as well as the 14th Festival Cinema Africano d'Asia e 
America Latina in Milan (2004). A full retrospective was also devoted to his work on kykNET, the Afrikaans language TV channel of M-Net, and he received several lifetime achievement awards for his oeuvre (Botha 2006). During the 2006 Apollo Film Festival, an important platform for South African cinema, festival director Leon Van der Merwe organised a special tribute to Rautenbach, which included another lifetime achievement award.

\section{A new film 30 years later}

In his memoirs (Steinmair 2006) Rautenbach talked about a new project - the story of Abraham Pikaan. Close to Rautenbach's house Oulap (in the mountains) is a place called Vlakteplaas, a dry piece of land bordering the Swartberge (mountains). The community of Vlakteplaas is poor. Their life is dominated by the presence of a railway track. They observe the passing trains with the passengers behind the windows. Spaces inside the train where people elegantly eat drink and enjoy themselves. Everyone dreams about a day to get on the train to leave Vlakteplaas for a better life.

At the age of 79 years old Rautenbach directed his first film after 30 years. It is striking how close the plot of Abraham (2014) resembles Rautenbach's description of his main character's story and key moments in his life in his memoirs (Steinmair 2006). Rautenbach considers Abraham Pikaan as a Vincent van Gogh figure. He was a dreamer, but his dreams were just too big for his cranium.

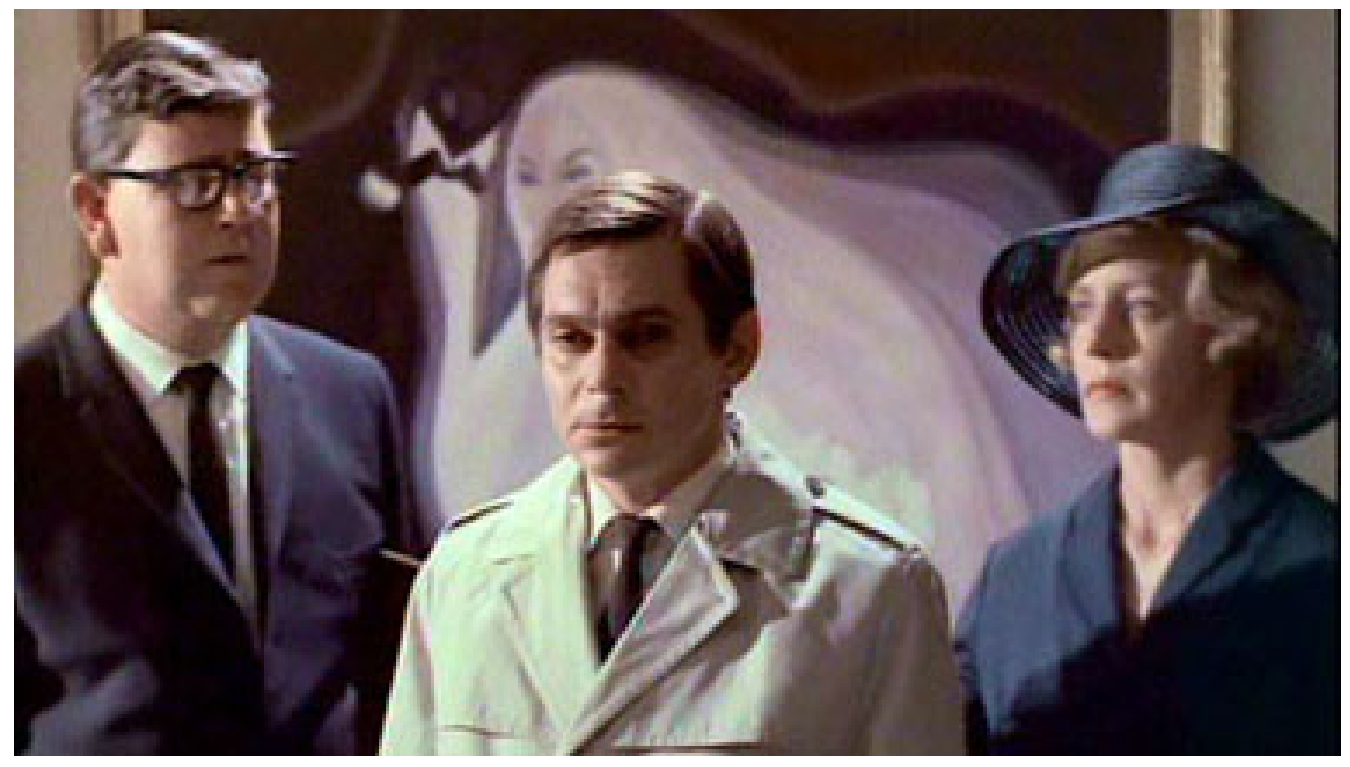

Figure 1: Jannie Totsiens (1970)

In the 1970s Rautenbach was at the peak of his film career. He and his wife Almeri bought a piece of land in the Vlakteplaas environment. They used rocks from the mountain to build the house. Rautenbach travelled between Oulap and Johannesburg for filmmaking. One day, on his way back from Johannesburg, Rautenbach met Abraham Pikaan. Pikaan informed him about a leopard, which he had made for the filmmaker. Rautenbach wasn't keen to listen and drove away. The next day Pikaan insisted that Rautenbach come and fetch his leopard, a sculpture. A while later similar incidents followed involving a range of sculptures of animals. Almeri convinced Rautenbach to offer Pikaan work on Oulap. He and his family (a wife and a daughter) moved into a small house - two bedrooms and a kitchen combined with a small dining room. One bedroom became Pikaan's studio.

Rautenbach gave him material to create the sculptures. Pikaan's life became complicated due to the alcohol dependency of his wife, Katie.

While in Johannesburg Rautenbach bought a book for Pikaan. It was a comprehensive visual documentation of animals around the world, an inspiration for the artist on Vlakteplaas. Rautenbach removed the book from a plastic bag. Pikaan was interested in the artwork on the bag: the outlines of a human skull with 
a key, which is used to open up the skull. Rautenbach told him that the book will open his mind to an amazing world beyond Vlakteplaas and a career as a true artist. Pikaan will be free. Pikaan took the book and announced to the female staff at Oulap that he is now a free man and that he will leave Vlakteplaas and its poverty.

During a function at Rautenbach's house, one of the staff on Oulap informed the filmmaker that Pikaan had been killed in a car accident. Rautenbach desperately looked for clues in the house of Pikaan. The studio was destroyed. Pikaan's wife tore the book apart and used an axe to destroy all the furniture. Pikaan had left and stood in the middle of the road. He had waited for a truck to run him over. According to Rautenbach's memoirs Pikaan wanted to be free - even if it meant that his skull literally should have been opened...

My first impression of the film Abraham (2014) was that it will be complicated for a mainstream South African audience. The current revival in Afrikaans cinema is based on escapism and nostalgia and in many ways resembles the cinema of the 1970s. In his current PhD study about contemporary Afrikaans cinema, Chris Broodryk focuses on Afrikaans film as a cinema of political impotence. With very few exceptions, Afrikaans cinema does not reflect the processes of political engagement and interrogation as other, ostensibly similar post-conflict cinemas do. While German filmmaker Rainer Werner Fassbinder's films made reference to Germany's "monstrous" political pasts and presents, Afrikaans cinema seems oblivious to its own "indebtedness" to a specific identifiable historical "monstrosity".

It is not that Afrikaans cinema attempts to "represent the unrepresentable", as Elsaesser (2001:195) puts it, but that there is no acknowledgement of anything unrepresentable (history, exploitation, political killings, effects of migrant labour and so forth) to engage with. Since 1994, Afrikaans cinema has abandoned its occasional sense of political urgency in its near totality in favour of what can broadly be described as safe, sanitised non-political narratives, films that fail to transcend their genre trappings and seem to reify stereotypes of Afrikaans-speaking South Africans in especially comedies, to not even mention the conspicuous absence of blackness in these films.

In his ongoing study, Broodryk will present a detailed examination of the claim that Afrikaans cinema has indeed shifted from occasional political potency to near complete political impotence. He was personally drawn to the issue of cinematic impotence by a growing realisation that Afrikaans cinema is a cinema that fails to come to grips with South African history and politics in general, a cinema that finds a critical engagement with the multicultural South African present equally problematic.

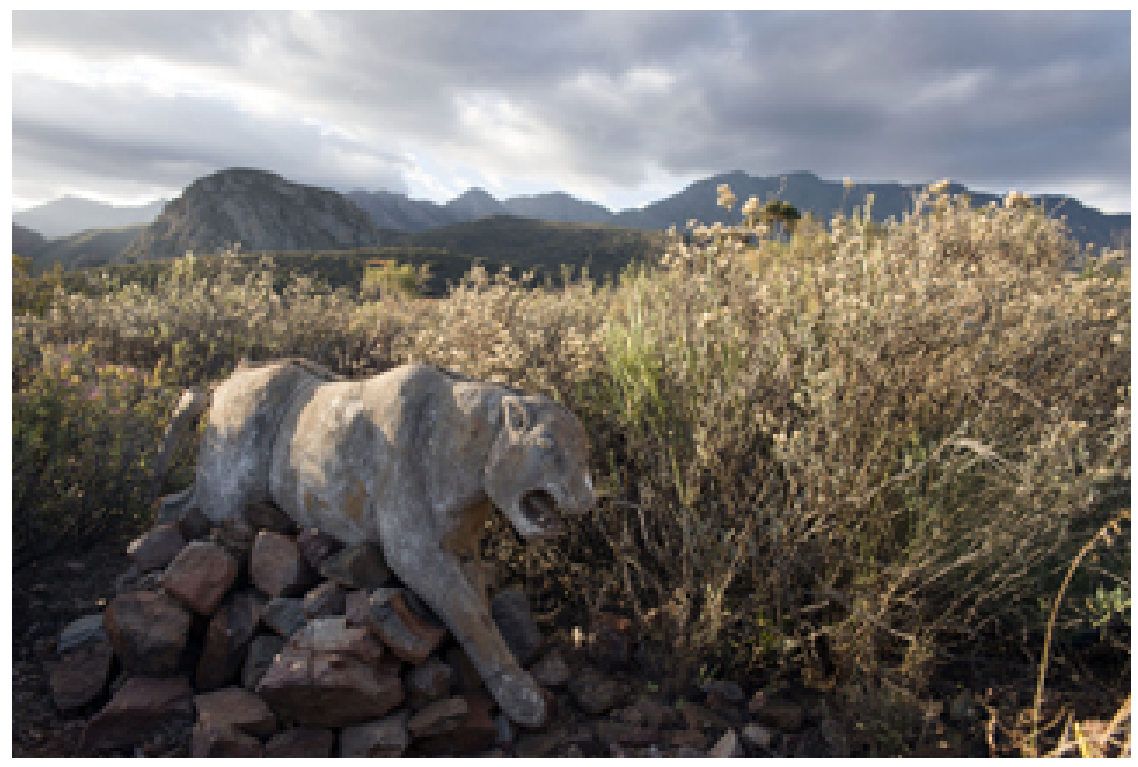

Figure 2: The Leopard by sculptor Abraham Pikaan

As in the case of his work of the 1960s, Rautenbach's new film will also be surrounded by an ocean of 
Afrikaans escapist fare. Abraham is a complex, very personal semi-autobiographical film. In order to fully appreciate and understand Rautenbach's vision, a contemporary audience needs a thorough exposure to the auteur's oeuvre, his career history, his life on Vlakteplaas. Oulap is an important character in the film. It is almost a place of reference to Rautenbach's life and career as film director. It contains important artefacts from Rautenbach's film oeuvre: paintings, sculptures, props from film sets and even the door used in the boardroom scenes of Die Kandidaat.

Oulap is a setting in Abraham, which transcends time. When Abraham is invited by Almeri to look at the artworks in the house, it feels like the present (2014), not during the seventies or early eighties, which is the time setting for the film. Rautenbach literally opens his home, a private space, to an audience. Although a caption at the beginning of the film suggests that some of the events of the story may be factual, an uncertainty has been created that other incidents may be based on legend. It allows Rautenbach to experiment with time and space. It also enables him to use the film medium to examine his relationship with Abraham. Rautenbach's representation of himself is critical. He is depicted as lacking patience, empathy and compassion during the first few encounters with Abraham. It is ironic that his sensitive representation of coloureds and their hardship in Katrina contrasts with his treatment of Abraham. For Rautenbach, Abraham is initially a nuisance. It is quite a contrast to the characters in Katrina.

The self-criticism is maintained throughout Abraham, especially with regard to the depiction of two worlds - Oulap's good life as opposed to the misery and poverty of Abraham's family. It is almost if the children on Oulap exist in a bubble of comfort, while Abraham is struggling. They are running around the pool while he is in their presence, but invisible to them.

Rautenbach uses his film to express regret. At the beginning and end of Abraham, he (as the 79-year-old filmmaker, playing himself) meets the daughter of Abraham Soetland (the surname was changed in the film). He asks her for forgiveness. In an earlier version of the film he is almost in tears. It is highly personal and very moving. Rautenbach realises that there has been a major paradox between the representations of his characters in Katrina and Broer Matie and his almost initial indifference to a real-life coloured male, Abraham Soetland and his anguish. Rautenbach's attitude towards Abraham changes when Soetland opens his shirt and asks the director whether he notices how he is bleeding.

In many ways Abraham is a textbook of Rautenbach's thematic preoccupations in earlier work: cultural identity, life during apartheid and suicide, a theme which the recent work shares with Katrina, Jannie Totsiens and Ongewensde Vreemdeling. Abraham however, breaks new ground: it is a sort of public confession by Rautenbach about white privilege and the marginalized. The film contrasts a world of privilege and a world of poverty, and of artists in both worlds. It examines relationships between white and black South Africans during apartheid. In one scene, Abraham's wife tells him that he is nothing and remains the white man's hotnot. ${ }^{(2)}$ In another scene Abraham desperately tries to sell his sculptures to motorists. It is almost a futile exercise and also humiliating. A truck driver throws the money through his truck's window at Abraham.

The main character's anguish is further emphasized by the use of Riku Lätti's songs and choirs in the film. The evocative music creates an almost unbearable sense of melancholy. Throughout his oeuvre, Rautenbach made brilliant use of music.

\section{Conclusion}

As in the case of Jannie Totsiens, which was released in the 1970s in an ocean of Afrikaans cinematic escapism (see Botha \& Van Aswegen 1992; Botha 2012), Abraham will also grace South African screens in a time of escapism - in Chris Broodryk's words, a time when Afrikaans film has become a cinema of political impotence. The reception of Rautenbach's most personal, semi-autobiographical reflection on white privilege and indifference, art, poverty and anguish will be interesting.

\section{Notes}

1. Afrikaners are a Southern African ethnic group descended from predominantly Dutch settlers first arriving in the seventeenth and eighteenth centuries. They have traditionally dominated South Africa's politics 


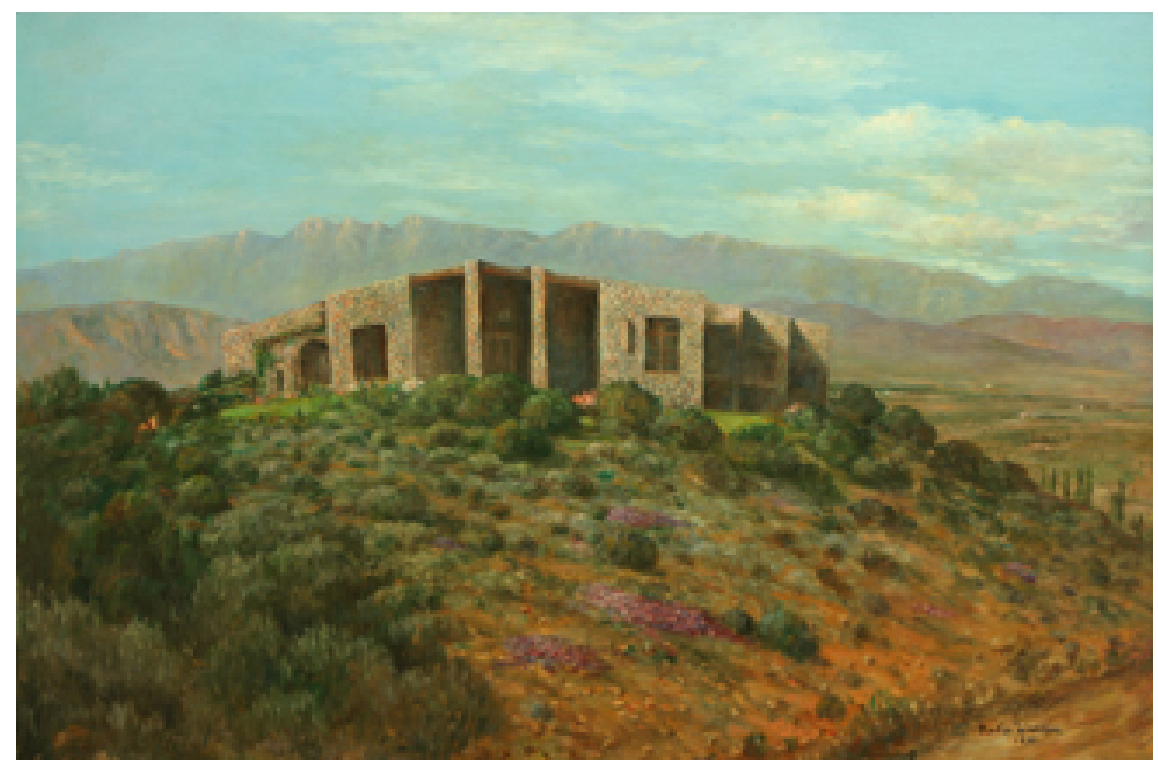

Figure 3: The Oulap - a setting

and agriculture (see Giliomee 2003). Afrikaans, South Africa's third most widely spoken home language is the mother tongue of Afrikaners and most so-called Cape Coloureds. The dialect evolved from the Dutch vernacular of South Holland, incorporating words brought from Indonesia and Madagascar by slaves. Afrikaners make up approximately $5.2 \%$ of the total South African population based on the number of white South Africans who speak Afrikaans as a first language in the South African National Census of 2011.

In Southern Africa, Cape Coloureds is the name given to an ethnic group composed primarily of persons of mixed race. Although Cape Coloureds form a minority group within South Africa, they are the predominant population group in the Western Cape. They are generally bilingual, though some speak only Afrikaans, and others primarily speak English. Some Cape Coloureds may "code switch" speaking a patois of Afrikaans and English called Kaapse Afrikaans. Cape Coloureds were defined under the apartheid regime as a subset of the larger Coloured race group.

2. Now widely considered an offensive ethnic slur, the term refers to coloureds in colonial and apartheid South Africa.

\section{References}

Blignaut, J. \& Botha, M.P. (eds) Movies moguls mavericks: South African cinema 1979-1991. Cape Town, Showdata, 1992.

Botha, M.P. Jans Rautenbach: Dromer, baanbreker en auteur. Kaapstad, Genugtig!, 2006.

Botha, M.P. (ed.). Marginal lives and painful pasts: South African cinema after apartheid. Cape Town, Genugtig!, 2007.

Botha, M.P. South African Cinema 1896 - 2010. Bristol, Intellect, 2012.

Botha, M.P. \& Van Aswegen, A. Images of South Africa: The rise of the alternative film. Pretoria, Human Sciences Research Council, 1992.

Elsaesser, T. 2001. Postmodernism as mourning work. Screen, 42:2, pp. 193-201.

Giliomee, H. The Afrikaners: Biography of a people. Cape Town, Tafelberg, 2003.

Steinmair, D. Jans, Droomsaaier: Sy Memoirs. Kaapstad, Genugtig!, 2006. 
Tomaselli, K.G. The cinema of apartheid: Race and class in South African film. London, Routledge, 1989.

\section{Selected Filmography}

Wild Season (1967)

Director: Emil Nofal

Screenplay: Emil Nofal, Jans Rautenbach

Cinematography: Vincent Cox

Die Kandidaat (1968)

Director: Jans Rautenbach

Screenplay: Jans Rautenbach, Emil Nofal

Cinematography: Vincent Cox

Katrina (1969)Director: Jans Rautenbach

Screenplay: Jans Rautenbach, Emil Nofal

Cinematography: Vincent Cox

Jannie Totsiens (1970)

Director: Jans Rautenbach

Screenplay: Jans Rautenbach

Cinematography: Koos Roets

Pappa Lap (1971)

Director: Jans Rautenbach

Screenplay: Jans Rautenbach

Cinematography: Koos Roets

Ongewensde Vreemdeling (1974)

Director: Jans Rautenbach

Screenplay: Jans Rautenbach

Cinematography: Vincent Cox

Eendag Op 'n Reëndag (1975)

Director: Jans Rautenbach

Screenplay: Jans Rautenbach

Cinematography: Koos Roets

Blink Stefaans (1981)

Director: Jans Rautenbach

Screenwriter: Jans Rautenbach

Cinematographer: Paul Marais

Broer Matie (1984)

Director: Jans Rautenbach

Screenwriter: Jans Rautenbach

Cinematographer: James Robb

No One Cries Forever (1984)

Director: Jans Rautenbach

Screenwriter: Jans Rautenbach

Cinematography: Hans Kuhle

Abraham (2014)

Director: Jans Rautenbach

Screenplay: Jans Rautenbach

Cinematography: Koos Roets 


\section{Reports}

Photo credits: J. Rautenbach photos: courtesy of Jans Rautenbach

\section{Author Information}

Martin P. BOTHA is Associate Professor of Film and Media Studies at the University of Cape Town. He has published more than 200 articles, reports and papers on South African media, including six books on South African cinema. His most recent book is South African Cinema 1896-2010 (Bristol: Intellect, 2012). 